DOI 10.37882/2223-2982.2021.09.13

\title{
ПРОБЛЕМЫ ИНДИВИДУАЛИЗАЦИИ МУЗЫКАЛЬНОГО ОБУЧЕНИЯ С ПОЗИЦИИ ИСТОРИЧЕСКОГО АНАЛИЗА
}

\section{PROBLEMS OF INDIVIDUALIZATION OF MUSIC EDUCATION FROM THE POSITION OF HISTORICAL ANALYSIS}

M. Korosteleva

Summary: The article analyzes the possibility of an individual approach in musical pedagogy. The article examines the points of view of famous composers who were also engaged in pedagogical activity and sought to develop the individuality of their students. Based on the study of the early stages of music education, the authors point out the reasons for the problems associated with the individualization of music education in the context of mass music education in Russia.

Keywords: the individualization, individual approach, individual training, professional music education, the system of mass music education.

\author{
Коростелева Мария Олеговна \\ Дочент, Тюменский государственный \\ институт культуры \\ movarta@mail.ru
}

Аннотация: В статье проводится анализ возможности индивидуального подхода в музыкальной педагогике. В статье исследуются точки зрения знаменитых композиторов, которые также занимались педагогической деятельностью и стремились к развитию индивидуальности у своих учеников. На основе исследования ранних этапов музыкального образования указываются причины проблем, связанных с индивидуализацией музыкального обучения в условиях массового музыкального воспитания в России.

Ключевые слова: индивидуализация, индивидуальный подход, индивидуальное обучение, профессиональное музыкальное образование, система массового музыкального воспитания.

инструментах;

- закрепились основные способы обучения грамотности, что достигалось путем заучивания и переписывания священных текстов и решения математических задач [14].

С появлением первых массовых школ, сразу обострилась проблема, касающаяся индивидуализации педагогических подходов к ученику, но в то же время массовое музыкальное образование способствовало интенсификации исследований теоретических и методологических вопросов.

Идея индивидуального подхода в отечественной музыкальной педагогике высказывалась В.Ф. Одоевским, который считал, что абсолютной педагогической методики не существует и не может быть разработано. Методика, реализуемая педагогом, формируется, по мнению В.Ф. Одоевского, даже не самим педагогом, а учеником, с которым взаимодействует педагог. В.Ф. Одоевский призывал отыскать «сокровище», в качестве которого рассматривал ученика, «который меньше всех знает и всех тупее» [9].

Современные исследователи биографии и педагогической деятельности В.Ф. Одоевского показывают, что он считал, что именно ученики со слабыми музыкальными способностями являются источником для построения методики преподавания, потому что преподаватель будет подбирать методы преподавания в соответствии с разумением своего ученика. Необходимость индивиду- 
альной методики обосновывалась В.Ф. Одоевским индивидуальностью самого ученика, так как, по его высказыванию, нельзя найти двух учеников с равными знаниями и способностями [8].

Индивидуальность обучающегося важна не только при обучении вокалу, игре на музыкальном инструменте, но и при обучении хоровому пению или при обучении игре в музыкальном оркестре, где индивидуальность музыканта или поющего человека может проявляться в очень ограниченных рамках. Отечественные исследователи во все времена музыкального образования и во всех его направлениях исследовали возможность индивидуального подхода к каждому ученику в соответствии с его совокупностью знаний, умений и способностей [1].

Виртуозы западноевропейского клавирного искусства Средних веков в своих трудах отмечали важность индивидуального подхода к обучению. Мнение специалистов данного направления важно еще и потому, что индивидуальный урок является основой для обучения музыкальному искусству. Например, фортепиано или пианино являются такими музыкальными инструментами, при обучении игре на которых требуется личностный контакт педагога с учеником. В.П. Сраджев пишет в своей монографии о том, что особенность обучения игре на фортепиано обусловлена специфичностью предмета изучения. Обучение игре на фортепиано связано с творческими озарениями обучающегося, которые оказывают влияние на формирование исполнительской техники [11].

B XVI - XVIII веках преобладали клавишно-щипковые инструменты, предшествовавшие фортепиано. В данный период времени издавались многочисленные руководства по обучению игре на клавишных инструментах, но основное внимание авторы уделяли положению пальцев, посадке музыканта относительно инструмента, манере игры, упражнениям для пальцев. Однако отдельным аспектом в этих трудах выступала роль педагога в становлении музыканта. М. Сен-Ламбер писал, что у профессионального педагога столько же методов преподавания, сколько у него учеников [10].

Позднее известные композиторы и музыканты постоянно говорили в своих трудах об индивидуальности каждого ученика и о необходимости учета индивидуальности при составлении плана преподавания и методов его реализации. Е.В. Мамай в своем диссертационном исследовании отметила внимание композитора Ф. Шопена к индивидуальности учеников, его стремление найти нужную форму воздействия для каждого ученика. Ф. Шопен считал, что ученик должен проявлять творческую инициативу и быть оригинальным в исполнении произведений, даже если практика исполнения музыкального произведения сложилась [7].
Современные исследователи отмечают, что Ференц Лист внес значимый вклад в педагогику в сфере игры на фортепиано. Ференц Лист получил музыкальное образование от К. Черни за полтора года, но кроме навыков эстрадных выступлений он унаследовал от учителя убежденность в том, что любое произведение должно исполняться с оригинальностью, присущему только ему. При исполнении музыкальных произведений Лист легко читал ноты, мог легко аккомпанировать и импровизировал [13].

Современники Ференца Листа восхищались его манерой вести уроки со своими учениками. Во-первых, уроки фортепианного мастерства проходили на высоком энергетическом уровне, а, во-вторых, уроки проводились в самых разнообразных формах. Ференц Лист практиковал уроки-беседы, уроки-демонстрации, уроки-семинары. Хотя Ференц Лист уделял особое внимание технике исполнения, но она не была самоцелью обучения, потому что Лист внушал своим ученикам, что они должны проникнуться произведением, пропустив его через собственные чувства и личностные качества, и исполнить произведение уже по собственному чувствованию [3].

Основным принципом педагогической политики Ф. Листа был принцип раскрытия индивидуальных способностей ученика. Ференц Лист понимал, что он меняет учеников, воздействуя на них педагогическими приемами, но он постоянно повторял, что ученик, меняясь, должен оставаться самим собой. Во время занятий Ференц Лист помогал своим ученикам обнаружить свои индивидуальные черты и в соответствии с ними наделял каждого ученика знаниями и умениями [12].

Во второй половине XIX века в отечественном музыкальном образовании внедрялись демократические взгляды, поэтому русские музыкальные педагоги стали уделять внимание индивидуальному подходу к каждому ученику. В этот период были решены многие проблемы музыкально-эстетического воспитания, так как в Москве и Петербурге стало больше возможностей для развития музыкальной педагогики.

Н.Г. Рубинштейн создал в Петербурге Русское музыкальное общество и осуществлял педагогическую деятельность с твердым убеждением, что к каждому ученику нужен свой подход. Н.Г. Рубинштейн высказывался о том, что каждый ученик имеет свои слабые стороны, и обязанность педагога в том, чтобы выявить эти слабые стороны и работать над их преодолением. А.Г. Рубинштейн и Н.Г. Рубинштейн называются в научной литературе преподавателями нового типа, так как они реализовали в своей деятельности новые принципы артистической педагогики, обеспечив развитие русского фортепианноисполнительского искусства и основав русскую пиани- 
стическую школу [4].

В 1920 - 1960-х годах российскими создателями исполнительских школ были изданы педагогические концепции, в которых особое внимание уделялось индивидуальным способностям обучающихся. Так, Л.В. Николаев писал, что каждый ученик индивидуален, и педагог не только должен развивать эту индивидуальность, но и одновременно с этим формировать индивидуальный исполнительский стиль ученика. По мнению Л.В. Николаева, должно происходить взаимное обогащение индивидуальностей педагога и учащегося, и основным фактором для этого должны быть естественные условия обучения [2].

В современной музыкальной педагогике никто не оспаривает особой значимости индивидуального подхода, и эта идея присутствует во всех исследованиях, касающихся начального и высшего музыкального образования.

О.С. Литвиненко считает, что рассмотрение проблемы индивидуального подхода в ретроспективном ракурсе позволяет выделить характерные особенности этого направления:

- необходимость изучения и учета в педагогическом процессе способностей, наклонностей и воз- можностей каждого учащегося;

- создание индивидуальных методик и планов работы в зависимости от индивидуальных особенностей ученика;

- воспитание творческой инициативы и самостоятельности в интерпретации исполняемого произведения;

- особая роль инициативы педагога, его умения и мастерства в реализации индивидуального потенциала личности каждого учащегося [6].

На основании вышеизложенного можно сказать, что внедрение массового музыкального образования очень затруднило практику индивидуального подхода к каждому учащемуся. Однако исследование исторических документов и научных трудов композиторов, которые оставили заметный след в истории музыкальной педагогики, показывает, что в России и за рубежом педагоги находили решение данной проблемы.

Исторический анализ свидетельствует, что педагоги стремились сформировать индивидуальность музыканта, но в то же время индивидуальным особенностям не всегда отдавался приоритет, что обусловливалось идеологией государств или преобладающими принципами общей педагогики.

\section{ЛИТЕРАТУРА}

1. Александров Е.П. Теория и практика дифференцированного подхода к музыкальному воспитанию учащихся общеобразовательной школы: Автореферат диссертации на соискание ученой степени кандидата педагогических наук. Специальность: 13.00.01. - 0бщая педагогика; история педагогики и образования. - Ростов н/Д.: Издательство Южного федерального университета, 1999. - 48 с.

2. Архангельская В.Д. Музыкально-педагогические воззрения и деятельность Леонида Владимировича Николаева (1878 - 1942): Автореферат диссертации на соискание ученой степени кандидата педагогических наук. Специальность: 13.00.01. - 0бщая педагогика, история педагогики и образования. - Казань: Издательство Казанского (Приволжского) федерального университета, 2012. - 24 с.

3. Галимуллина А.Р. Педагогическая система Ф. Листа / Наука и образование в контексте культурных традиций: Материалы научно-практической конференции. - М.: Издательство «Перо», 2018. - С. $79-89 .-346$ с.

4. Гарань Н.Ф. Педагогическая деятельность Антона и Николая Рубинштейнов. - Магнитогорск: Издательство Магнитогорской государственной консерватории (академии) имени М.И. Глинки // Российские педагогические ассамблеи искусств в Магнитогорске. - 2018. - №24. - С. 27 - 39.

5. Герцман Е.В. Музыкально-педагогические системы: античная музыкальная педагогика: Учебное пособие для вузов. - М.: Издательство «Юрайт», 2020. $-77 \mathrm{C}$.

6. Литвиненко 0.С. Индивидуализация музыкального обучения школьников как педагогическая проблема / Традиции и инновации в современном культурно-образовательном пространстве: Материалы VII Международной научно-практической конференции. - М.: Издательство Московского педагогического государственного университета, 2016. - С. $217-221 .-414$ с.

7. Мамай Е.В. Педагогические взгляды Ф. Шопена и современность (на материале работы в музыкально-исполнительских классах педагогических учебных заведений): Автореферат диссертации на соискание ученой степени кандидата педагогических наук. Специальность: 13.00.02. - Теория и методика обучения и воспитания (по областям и уровням образования). - М.: Издательство Московского педагогического государственного университета, 2004. $-20 \mathrm{C}$.

8. Николаева Е.В. Индивидуально-личностный подход к учащимся на начальном этапе обучения хоровому пению. - М.: Издательство Московского педагогического государственного университета // Музыкальное искусство и образование. - 2020. - Т. 8. - №2. - С. 140 - 160.

9. Одоевский В.Ф. Музыкально-литературное наследие: Монография. - М.: Государственное музыкальное издательство, 1956. - 723 с.

10. Панов А.А., Розанов И.В. От клавира к пианофорте. Постановка рук и посадка за инструментом в последней трети XVIIII - начале XIX века. - M.: Издательство 000 «Литературное агентство ПРЕСТ» // Старинная музыка. - 2020. - №2(88). - С. 26 - 40. 
11. Сраджев В.П. Творческое мышление и воспитание музыканта: Монография. - М.: Издательство «Прогресс», 2007. - 120 с.

12. Сунь Ц. Педагогические принципы Ф. Листа и современность (на материале книги А. Буасье «Уроки Листа»). - СПб.: Издательство Санкт-Петербургского университетского консорциума // Университетский научный журнал. - 2020. - №58. - С. 103 - 108.

13. Ханафеева Д.В., Богданова О.В. Ференц Лист. Творческий облик / Воспитание будущего учителя-исследователя: Сборник материалов по итогам научной сессии студентов. - Глазов: Издательство Глазовского государственного педагогического института имени В.Г. Короленко, 2019. - С. 280 - 285. - 474 с.

14. Шарухин А.П., Шарухина Т.Г. История образования: периодизация и тенденции развития. - СПб.: Издательство Санкт-Петербургского университета Министерства внутренних дел Российской Федерации // Вестник Санкт-Петербургского университета МВД России - 2018. - №2(78). - С. 229 - 233.

\section{○ Коростелева Мария Олеговна (movarta@mail.ru).}

Журнал «Современная наука: актуальные проблемы теории и практики»

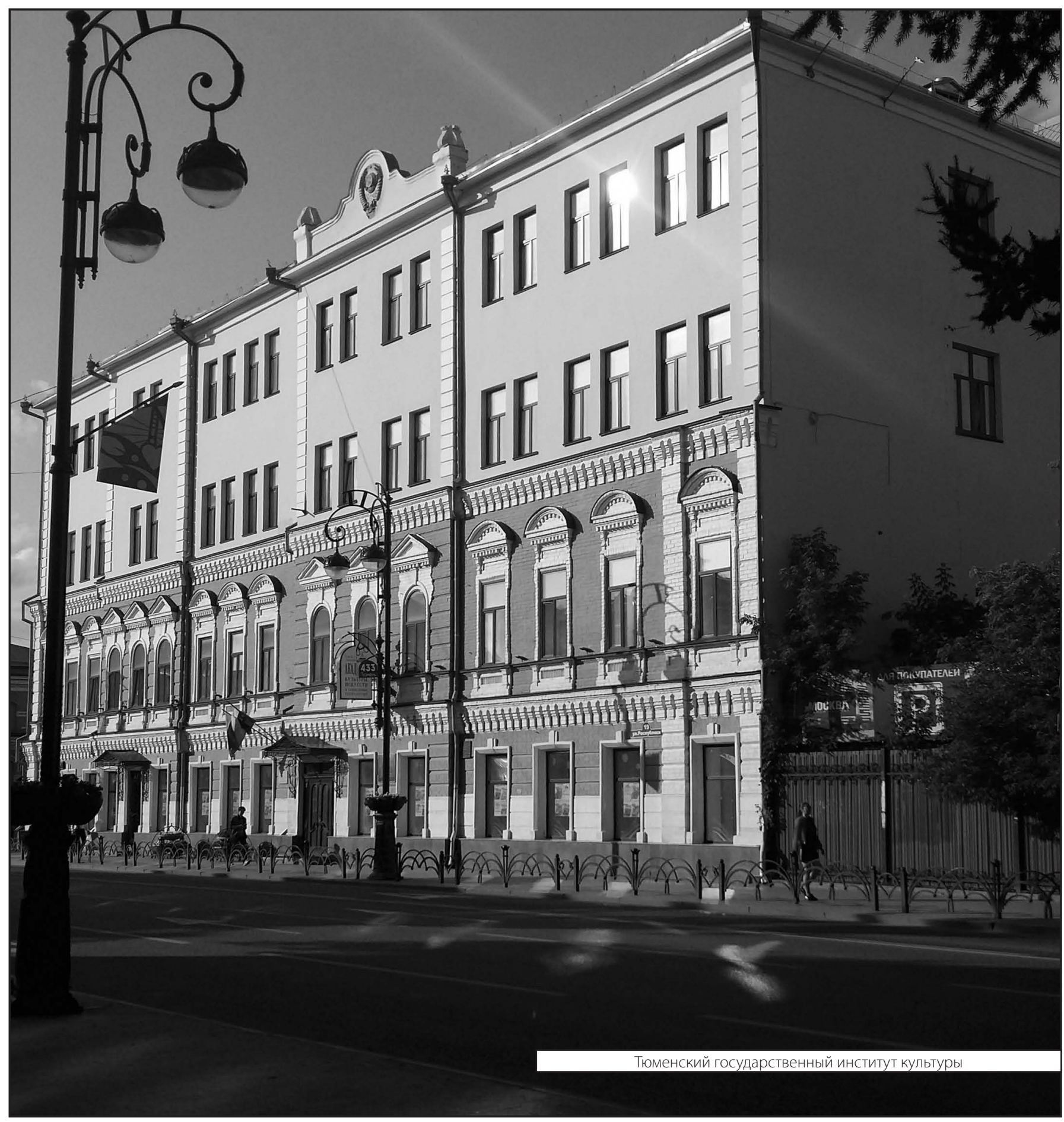

